\title{
Histone Deacetylase 9
}

National Cancer Institute

\section{Source}

National Cancer Institute. Histone Deacetylase 9. NCI Thesaurus. Code C102494.

Histone deacetylase 9 (1011 aa, $111 \mathrm{kDa}$ ) is encoded by the human HDAC9 gene. This protein plays a role in the modification of chromatin structure. 